\title{
Klasifikasi dan Identifikasi Jumlah Koloni Pada Citra Bakteri Dengan Metode K-Nearest Neighbor
}

\author{
Ihsan, Rahmadwati, Herman Tolle
}

\begin{abstract}
This study proposes a system for classification and counting the number of bacterial colonies using a photo image of bacteria. The system uses several image pretreatment process. Including Contrast Stretching, Extended-Maxima Transform, and Regionprops. The main purpose of this system is to determine the category of colonies of bacteria in large quantities can not be done manually. To build the algorithms necessary features must be determined such as diameter, perimeter and roundness method of determining the categories using KNN (K-Nearest Neighbor). As a results of this research is classify three types of bacteria such as Lactobacillus Bulgaricus, Streptococcus thermophiles, and bifidobakterium Precision with a percentage of $97,97 \%$ and $87,09 \%$ F-Measure
\end{abstract}

Keywords: Contrast Stretching, Lactobacillus, Regionprops, K-Nearest Neighbor

Abstrak - Penelitian ini mengajukan suatu sistem untuk melakukan klasifikasi dan penghitungan jumlah koloni bakteri dengan menggunakan citra foto bakteri. Sistem ini menggunakan beberapa proses prapengolahan citra. Seperti Contrast Stretching, Extended-Maxima Transform, dan Regionprops. Tujuan utama dari sistem ini adalah menentukan kategori dari koloni bakteri dalam jumlah besar tidak mungkin dilakukan secara manual. Untuk membangun algoritma tersebut perlu fitur-fitur yang harus ditentukan yaitu diameter, perimeter, dan roundness metode penentuan kategori menggunakan $K N N$ (K Nearest Neighbor). Hasil penelitian mengklasifikasikan 3 jenis bakteri yaitu Lactobacillus Bulgaricus, Streptococcus Thermophiles, dan Bifidobakterium dengan presisi 97,97 dan F-Measure 87,09\%.

Kata kunci : Contrast Stretching, Lactobacillus, Regionprops, K-Nearest Neighbor

Manuscript received October 24, 2016. (Write the date on which you submitted your paper for review.) This work was supported in part by Electrical Engineering Department University of Brawijaya Ihsan is with the Electrical Engineering Departement, Faculty of Engineering, Brawijaya University, Malang, Indonesia (email:hamidmustamin@gmail.com)

Rahmadwati was the Electrical Engineering Departement, Faculty of Engineering,Brawijaya University, Malang, Indonesia (rahma@ub.ac.id)

Erni Yudaningtyas is Electrical Engineering Departement, Faculty of Engineering,Brawijaya University, Malang, Indonesia (herman.class@gmail.com)

\section{PENDAHULUAN}

Denelitian di bidang mikrobiologi terutama bakteri seringkali berpatokan pada penentuan jumlah koloni atau Colony Forming Units (CFUs) yang akurat. Penentuan jumlah koloni dapat dilakukan dengan menghitung jumlah koloni bakteri secara manual. Proses perhitungan secara manual terhadap keseluruhan penampang membutuhkan waktu yang lama, sehingga muncul metode untuk menghitung bagian tertentu dari cawan petri untuk memperkirakan jumlah koloni pada keseluruhan cawan. Hal ini tentu akan memberikan hasil yang sangat tidak akurat karena sebagian besar bakteri tidak tumbuh secara merata di seluruh tempat pada cawan. Penghitungan koloni dapat juga dilakukan dengan bantuan alat bernama colony counter electronic yaitu dengan cara menandai koloni dengan pen yang terhubung dengan counter, namun hal ini tetap membutuhkan waktu yang lama dan membutuhkan konsentrasi yang tinggi dari peneliti bidang mikrobiologi. Sehingga dibutuhkan sistem yang mampu menghitung jumlah koloni secara otomatis dan cepat. [1]

Pada penelitian ini, dilakukan proses ekstraksi ciri berdasarkan diameter, perimeter, roundness. Ekstraksi ciri ini merupakan teknik dari pengolahan citra digital yang digunakan untuk membantu proses klasifikasi jenis bakteri agar mendapatkan hasil yang cukup akurat. Namun terdapat kelemahan karena hasil foto dari citra bakteri terdapat banyak noise sehingga objek yang didapat lebih banyak dari objek yang diharapkan. Untuk mengatasi hal tersebut, diperlukan Preprocessing sebelum melakukan ekstraksi ciri jenis bakteri agar hasil klasifikasi jauh lebih akurat dan tidak menunjukkan banyak noise yang terlalu berlebihan. [3]

Penelitian ini bertujuan untuk memudahkan dalam perhitungan jumlah koloni yang jumlahnya sangat banyak bahkan ratusan atau ribuan pada cawan petri, dan proses penghitungan biasanya secara manual dilakukan oleh para laboran mikrobiologi. Dalam penelitian ini, memperkenalkan suatu sistem otomatis dan efisien pada penghitungan dan klasifikasi koloni bakteri. [2]

Berdasarkan analisis pengekstrakan ciri, metode klasifikasi pada penelitian ini menggunakan klasifikasi secara langsung menggunakan data pembelajaran untuk 
menentukan kategori dari data baru yang ini ditentukan kategorinya. Metode ini dikenal dengan nama $K$ Nearest Neighbor (KNN).

\section{II.PERANCANGAN SISTEM}

Pada penelitian ini bakteri yang digunakan yaitu bakteri asam laktat untuk pembuatan yougurt diantaranya adalah Lactobacillus Bulgaricus, Streptococcus Thermophiles, Bifidobakterium. Tahapan pengambilan data dilakukan dengan serangkaian prosedur pengambilan data bakteri dasar asam laktat yang di ambil sendiri oleh peneliti kemudian di campurkan dengan media yougurt di laboratorium Mikrobiologi Universitas Brawijaya Malang. Data merupakan citra digital yang diambil menggunakan kamera digital dengan ukuran 500x500 piksel dengan format JPG, BMP dan lain-lain. Jumlah foto citra bakteri yang digunakan pada penelitian ini adalah 30 citra uji dan 57 data pembelajaran. Gambar 1 menunjukkan contoh dari salah satu data yang digunakan.

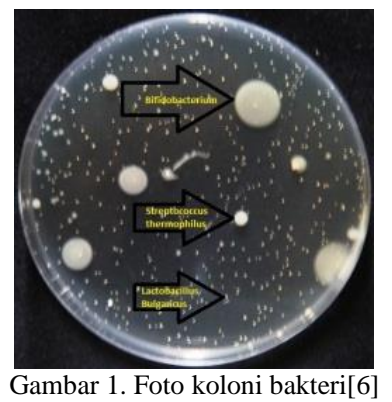

Pada gambar 1 terlihat penelitian ini menggunakan image segmentation menggunakan metode Thresholding untuk memisahkan antara citra terhadap background. Pengelompokan tergantung dari nilai diameter, perimeter, roundness dari koloni bakteri pada citra yang berbeda misalnya Bakteri Lactobacillus Bulgaricus memiliki ukuran dan bentuk yang lebih kecil daripada bakteri Streptococcus Thermophilus dan Bifidobacterium, Bakteri Streptococcus Thermophilus berukuran besar diantara bakteri Lactobacillus Bulgaricus dan Bifidobacterium, Bakteri Bifidobacterium memiliki ukuran paling besar diantara ketiga bakterinya.

Dalam penelitian ini terdapat analisis proses dalam memperbaiki kualitas citra hingga diketahui bagaimana hasil klasifikasi citra koloni bakteri. Proses awal dapat dilihat pada Gambar 2.

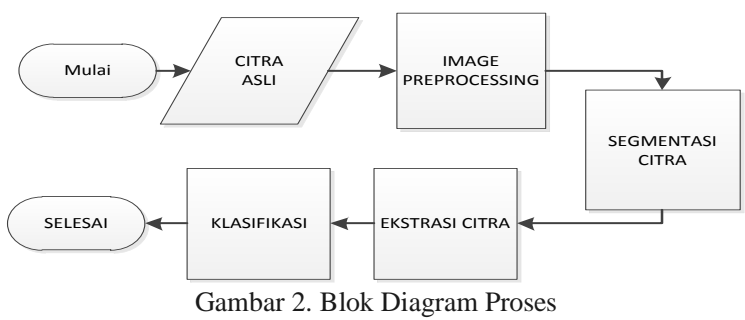

Proses preprocessing ini melibatkan beberapa langkah yang berfungsi untuk memperbaiki kualitas citra bakteri yang didalamnya terdapat penyakit pneumonia.

- Input citra yang berfungsi untuk memasukkan citra berupa foto koloni berformat jpg.
- Preprocessing berfungsi untuk memperbaiki dan mempertajam citra koloni bakteri untuk memudahkan dalam proses segmentasi citra

- Segmentasi citra pemisahan obyek yang diinginkan dari obyek yang lain. Berdasarkan warna-warna dominan yang terdapat pada citra bakteri, pada penelitian ini menggunakan Thresholding. Pada tahap ini segmentasi dilakukan berdasarkan warna dominan

- Ekstrasi ciri merupakan proses untuk mendapatkan ciri atau parameter yang akan digunakan untuk mendeteksi citra koloni bakteri untuk klasifikasinya. Informasi yang berhubungan dengan diameter, perimeter dan roundness.

- Klasifikasi adalah Proses akhir pada tahap ini dilakukan pengenalan yang terdiri dari training dan testing terhadap beberapa jenis bakteri

\section{HASIL DAN PEMBAHASAN}

A.Input

Input citra didalam penelitian ini menggunakan media foto koloni bakteri bertujuan untuk memulai program identifikasi dan klasifikasi jumlah koloni bakteri yang berformat .jpg, .tif, .bmp, dan lain-lain. Maka dari itu foto koloni bakteri merupakan bagian yang sangat penting dalam memproses obyek.

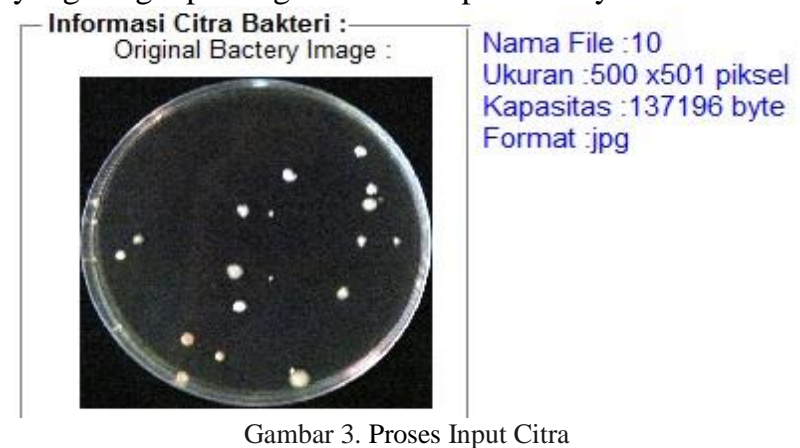

Berdasarkan gambar 3 dapat melihat sebuah informasi pada input citra ukuran, kapasitas dan format citra.

\section{B. Image Preprocessing}

Pada tahap ini, citra masukan hasil acquisition diperbaiki untuk mempertajam citra koloni bakteri untuk memudahkan dalam proses segmentasi citra dan luminansi selama image acquisition. Pada penelitian ini menggunakan contrast streaching. Berikut gambar 4 adalah Blok diagram proses Preprocessing dan gambar 4 hasil preprocessing contrast stretching

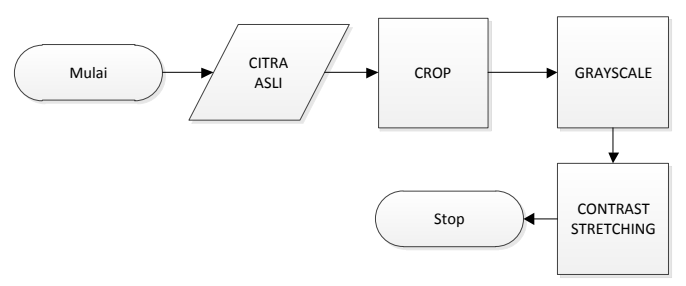

Gambar 4. Blok diagram Preprocessing Image 


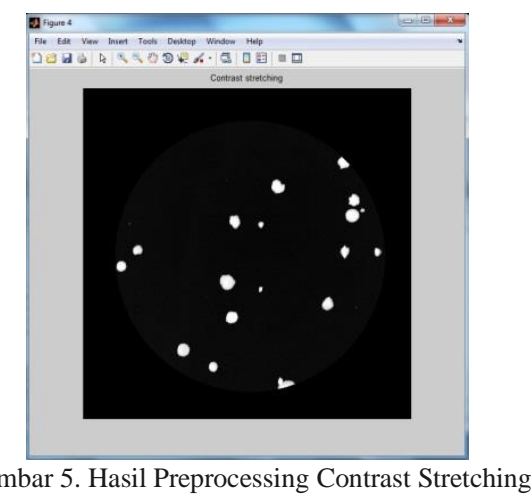

C. Segmentasi

Segmentasi citra merupakan bagian penting dalam banyak teknik pemrosesan citra digital. Prosedur segmentasi adalah untuk menemukan pola yang lebih baik dari bentuk yang ditampilan. Algoritma berdasarkan pengklasifikasi telah banyak diterapkan ke organ segmen di gambar medis seperti gambar jantung dan otak [7]. Pada penelitian ini menggunakan Thresholding. Pada tahap ini segmentasi dilakukan berdasarkan warna dominan Sehingga pada penelitian ini menggunakan image segmentation menggunakan metode Thresholding untuk memisahkan antara citra terhadap background. Banyaknya tergantung dari jenis bentuk, ukuran, luas area dari koloni bakteri pada citra yang berbeda misalnya Bakteri Lactobacillus Bulgaricus memiliki ukuran dan bentuk yang lebih kecil daripada bakteri Streptococcus Thermophilus dan Bifidobacterium, Bakteri Streptococcus Thermophilus berukuran besar diantara bakteri Lactobacillus Bulgaricus dan Bifidobacterium, Bakteri Bifidobacterium memiliki ukuran paling besar diantara ketiga bakterinya. Berikut gambar 6 adalah blok diagram proses segmentasi

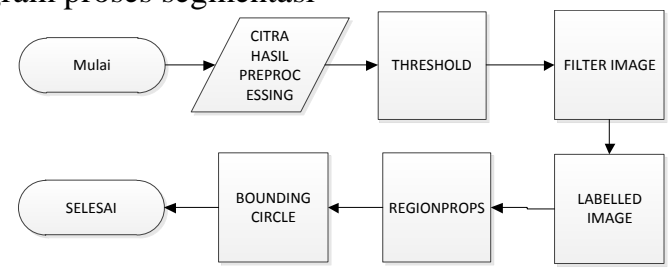

Gambar 6. blok diagram proses segmentasi

Langkah-langkah yang dilakukan pada proses ini ditunjukkan pada gambar 6 dan dapat dijelaskan sebagai berikut:

- Citra yang telah melewati proses preprocessing. Kemudian proses segmentasi untuk memisahkan obyek koloni bakteri dan background Threshold

- Proses segmentasi dilakukan banyak citra koloni bakteri yang kecil hilang untuk menampilkan citra yang hilang tersebut digunakan metode Extendedmaxima transform.

- Setelah citra difilter maka proses selanjutnya labelled image di aplikasi ini berfungsi untuk menentukan item koloni bakteri.

- Regionprops adalah salah satu metode deteksi tepi objek yang berfungsi untuk menentukan besar kecilnya koloni bakteri dan selanjutnya untuk mendukung proses ekstraksi fitur koloni bakteri.

Berikut gambar 7 adalah hasil dari proses segmentasi.

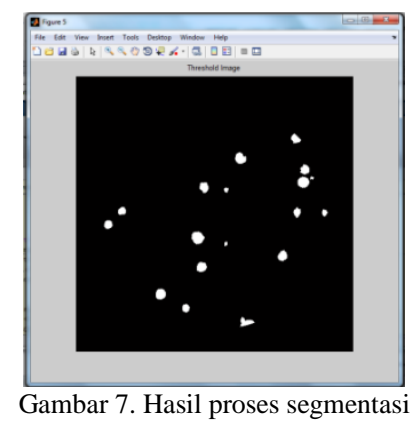

\section{D.Ekstraksi Fitur}

Ekstraksi Fitur adalah metode mengambil ciri-ciri visual yang ada pada citra gambar untuk pengambilan tingkat primitif atau rendah fitur citra dapat berupa fitur umum, seperti ekstraksi diameter, perimeter, dan roundness. [4]

Dalam sebuah citra terdapat banyak informasi yang bisa diolah, sehingga bisa menghasilkan suatu informasi baru yang sangat berguna. Proses penggalian informasi yang terkandung dalam sebuah citra sering disebut dengan ekstraksi fitur. Biasanya dalam ekstraksi fitur ada tiga jenis fitur yang sering digali informasinya, yakni diameter, perimeter, dan roundness. Berikut gambar 7 hasil proses ekstraksi fitur.

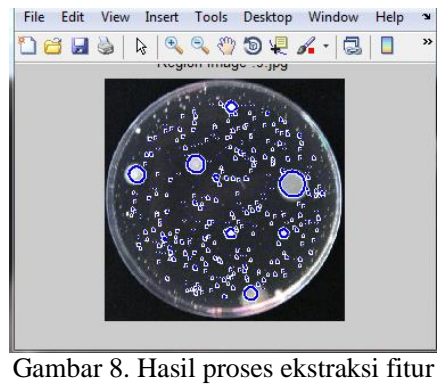

\section{E. Klasifikasi (K Nearest Neighbor)}

K-Nearest neighbors (KNN) adalah didasarkan bahwa ide dari KKN adalah pola terdekat terhadap pola target x', KNN memberikan kelas label mayoritas pola K-terdekat di ruang data. [5]

$$
\left\|x^{\prime}-x_{j}\right\|^{p}=\left(\sum_{i=1}^{q}\left|\left(x_{i}\right)^{\prime}-\left(x_{i}\right)_{j}\right|^{p}\right)^{1 / p}
$$

Berikut adalah blok diagram alur proses klasifikasi koloni bakteri:

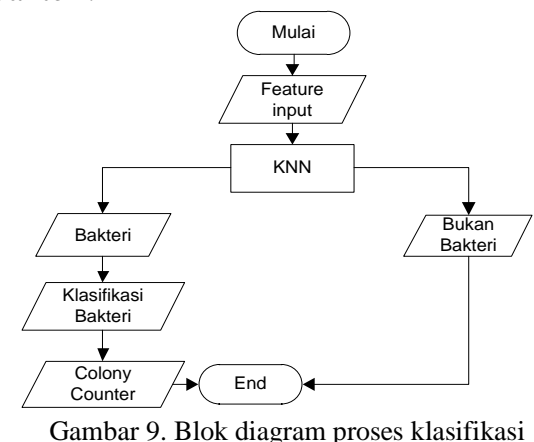

Pada proses klasifikasi menggunakan metode Regionprops dari ekstraksi fitur adalah bounding circle adalah sistem yang memiliki kemampuan untuk menentukan centroid dari citra baik itu berbentuk bulat atau tidak bulat. Kemudian mendeteksi batas objek yang dirujuk oleh citra. Sistem ini diimplementasikan 
menggunakan metode yang memiliki kemampuan untuk mendeteksi objek bergerak. Sehingga cocok pada penelitian ini karena bentuk koloni terkadang berbentuk bercak-bercak sehingga bisa dengan mudah dikenali polanya.

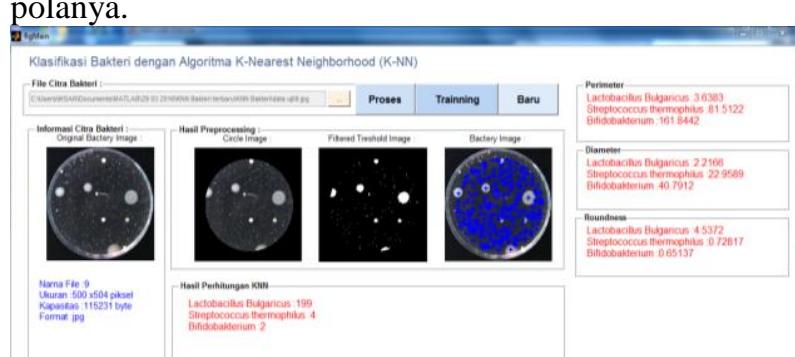

Gambar 10. Hasil proses penghitungan dan klasifikasi bakteri.

Dari gambar diatas hasil akhir dari penelitian ini adalah dapat mengklasifikasikan 3 jenis bakteri yaitu Lactobacillus Bulgaricus, Streptococcus Thermophilus, Bifidobacterium dan citra dapat mendeskripsikan batas dari objek citra. Koloni bakteri yang telah tersegmentasi mempunyai nilai dari diameter, perimeter, roundness yang digunakan sebagai acuan pada proses klasifikasi.

\section{F. Penilaian dan klasifikasi bakteri}

Tahap ini adalah pengujian pengklasifikasian citra koloni bakteri menjadi 3 jenis yaitu Lactobacillus Bulgaricus, Streptococcus Thermophilus, dan Bifidobacterium. Pengelompokan ini berdasarkan interview dengan beberapa laboran di universitas Brawijaya dan laboran di universitas UIN Maliki Malang.

Klasifikasi ini terinspirasi dari cara laboran menganalisa jenis bakteri. Sistem akan mengklasifikasikan 3 kelas bakteri dengan menggunakan ekstraksi fitur diameter, perimeter, dan roundness. Klasifikasi di asumsikan sebagai berikut :

1. Lactobacillus Bulgaricus

Diameter $<8$

Perimeter $<24$

2. Streptococcus Thermophilus

$8<$ Diameter $<22$

$24<$ Perimeter $<68$

3. Bifidobacterium

Diameter $>22$

Perimeter $>68$

Pengujian dilakukan pada 30 citra koloni dengan spesifikasi yang berbeda. Dari hasil pengujian tersebut, menunjukkan bahwa Diameter rata-rata citra koloni dibawah 8 dan perimeter dibawah 24 diidentifikasi koloni bakteri dari Lactobacillus Bulgaricus, Diameter rata-rata citra koloni diatas 8 dan dibawah 22 dan perimeter diatas 24 dan dibawah 68 diidentifikasi koloni bakteri dari Streptococcus Thermophilus, dan Diameter rata-rata citra koloni diatas 22 dan perimeter diatas 68 diidentifikasi koloni bakteri dari Bifidobacterium.

Gambar 10 memperlihatkan sistem klasifikasi bakteri. Setelah mengelompokkan data berdasarkan bounding circle, maka dapat dengan mudah jumlah bakteri dan kelasnya diklasifikasikan. Pada Tabel 1 menunjukkan hasil keakuratan klasifikasi menggunakan sistem
Tabel 1. Pengujian Sample Hasil Deteksi Koloni dengan Program

\begin{tabular}{|c|l|c|c|c|c|}
\hline $\begin{array}{c}\text { Nama } \\
\text { Citra }\end{array}$ & Nama Bakteri & Perimeter & Diameter & $\begin{array}{c}\text { Round } \\
\text { ness }\end{array}$ & $\begin{array}{c}\text { Jml } \\
\text { Koloni }\end{array}$ \\
\hline \multirow{3}{*}{1} & L. Bulgaricus & 17.8 & 6.0 & 1.0 & 32 \\
\cline { 2 - 6 } & S. Thermophilus & 39.6 & 11.3 & 0.7 & 10 \\
\cline { 2 - 6 } & Bifidobacterium & 0 & 0 & 0 & 0 \\
\hline \multirow{3}{*}{2} & L. Bulgaricus & 22.3 & 7.3 & 0.9 & 6 \\
\cline { 2 - 6 } & S. Thermophilus & 57.8 & 16.4 & 0.7 & 8 \\
\cline { 2 - 6 } & Bifidobacterium & 0 & 0 & 0 & 0 \\
\hline \multirow{3}{*}{3} & L. Bulgaricus & 9.3 & 3.7 & 1.4 & 281 \\
\cline { 2 - 6 } & S. Thermophilus & 49.0 & 14.0 & 0.6 & 9 \\
\cline { 2 - 6 } & Bifidobacterium & 143.7 & 41.9 & 0.8 & 3 \\
\hline \multirow{3}{*}{4} & L. Bulgaricus & 7.0 & 3.1 & 2.1 & 155 \\
\cline { 2 - 6 } & S. Thermophilus & 31.3 & 8.7 & 0.4 & 2 \\
\cline { 2 - 6 } & Bifidobacterium & 304.9 & 67.3 & 0.1 & 1 \\
\hline \multirow{3}{*}{5} & L. Bulgaricus & 9.3 & 3.7 & 1.4 & 281 \\
\cline { 2 - 6 } & S. Thermophilus & 49.0 & 14.0 & 0.6 & 9 \\
\cline { 2 - 6 } & Bifidobacterium & 143.7 & 41.9 & 0.8 & 3 \\
\hline \multirow{2}{*}{ Pengujan } & & & \\
\hline
\end{tabular}

Pengujian tentang precision dan recall hasil klasifikasi akan dibandingkan terhadap tingkat kebenaran dengan klasifikasi manual oleh para laboran [8]. Berikut nilai rata-rata Precision, Recall, dan FMeasure dari tiap-tiap bakteri dapat dilihat pada tabel 2 .

Tabel 2. Perbandingan nilai Precision, Recall, dan F-Measure

\begin{tabular}{|c|l|c|c|c|}
\hline No & Nama Bakteri & Precision & Recall & F-Measure \\
\hline 1. & L. Bulgaricus & $98,75 \%$ & $81,51 \%$ & $88,95 \%$ \\
\hline 2. & S. Thermophilus & $95,16 \%$ & $74,18 \%$ & $81,85 \%$ \\
\hline 3. & Bifidobacterium & $100 \%$ & $84,37 \%$ & $90,47 \%$ \\
\hline \multicolumn{2}{|c|}{ Rata-rata } & $97,97 \%$ & $80,02 \%$ & $87,09 \%$ \\
\hline
\end{tabular}

Dari tabel diatas prosentase dari Precision 97,97\% dan F-Measure $87,09 \%$ diatas menujukkan prosentase yang terbilang baik Hasil penelitian yang telah dilakukan, menunjukkan suatu kontribusi lebih baik dimana penelitian ini dengan penelitian sebelumnya sama-sama mengkaji mengenai Colony Counter perbedaannya penelitian sebelumnya oleh Wei-Bang Chen dan Chengcui Zhang (2011) dengan judul An automated bacterial colony counting and classification system menggunakan metode klasifikasi Support Vector Machine (SVM) dengan tingkat precision $96,00 \%$.

\section{KESIMPULAN}

Pada penelitian ini penghitungan dan klasifikasi jenis bakteri menggunakan deteksi bounding circle dengan metode Region Properties dan metode K-Nearest Neighbor untuk proses klasifikasinya dan telah dilakukan dan memberikan hasil yang cukup baik dengan prosentase rata-rata Precision 97,97\% dan FMeasure $87,09 \%$ untuk seluruh jenis bakteri. Ekstraksi ciri menggunakan metode Regionprops cukup baik untuk deteksi kountur koloni bakteri. Untuk dapat membedakan macam-macam jenis bakteri dan digunakanlah ekstraksi ciri diameter, perimeter dan roundness. Dalam proses identifikasi jenis bakteri diperlukan bantuan pengetahuan dari pakar mikrobiologi untuk membantu mengenali jenis bakteri tersebut. Sehingga identifikasi dan klasifikasi citra koloni bakteri sesuai dengan hasil yang diharapkan. 


\section{REFERENSI}

[1] Nilasari N.K.N., dkk. 2014. Identifikasi Jumlah Koloni Pada Citra Bakteri Dengan Metode Improved Counting Morphology. Repositori Jurnal Mahasiswa PTIIK UB Volume 4 - Number 2. Universitas Brawijaya, Malang.

[2] Chen W B., Zhang Chengcui., 2011. An automated bacterial colony counting and classification system. Springer Science and Business Media.

[3] Murinto., Harjoko A. 2009. Segmentasi Citra Menggunakan Watershed Dan Itensitas Filtering Sebagai Pre Processing. Seminar Nasional Informatika. Universitas Gajah Mada.

[4] Mohanaiah P., dkk. 2013. Image Texture Feature Extraction Using GLCM Approach. International Journal of Scientific and Research Publications, India.
[5] Kramer O. 2013. Dimensionality Reduction with Unsupervised Nearest Neighbors. Intelligent Systems Reference Library. Carl von Ossietzky University Oldenburg, Germany.

[6] Data citra koloni bakteri laboratorium mikrobiologi UIN Maliki Malang. "Citra bakteri Lactobacillus Bulgaricus, Streptococcus Thermophilus, Bifidobacterium". Malang, 2015.

[7] Aly A A., dkk., 2011. Research Review For Digital Image Segmentation Techniques. International Journal of Computer Science \& Information Technology (IJCSIT). Faculty of Computer Science, Universiti Teknologi Malaysia.

[8] Siahaan D., dkk., 2012. Sistem Pembangkit Anotasi Pada Artikel Bergambar Dengan Pendekatan Kontekstual. Institut Teknologi Sepuluh Nopember, Surabaya. 